УДК 821.1612 - 36.09: 398.23 (477)

Мельник Н. Г.,

кандидат філологічних наук, доцент, завідувач кафедри української та світової літератур

ДВНЗ «Криворізький державний педагогічний університет»

\title{
СУЧАСНИЙ УКРАЇНСЬКИЙ АНЕКДОТ ПРО МОСКАЛІВ: ДИНАМІКА ТРАДИЦІї
}

У статті досліджуються сучасні народні анекдоти про москалів. Акиентовано на розумінні анекдота як одного з найпродуктивніших та найпопулярніших фольклорних жанрів, здатного до трансформацій, пристосування до нових життєвих реалій.

Констатовано, щуо складність і неоднозначність фольклорного образу москаля, його національне на сочіальне трактування зумовлені історичними, політичними, психологічними особливостями української історії.

Ключові слова: народний анекдот, традичія, образ, москаль.

This article investigates modern folk jokes about Muscovites. It emphasizes that the anecdote is considered to be one of the most productive and popular folk genres, easy changeable in terms of new life realities.

This paper represents the fact that the complexity and ambiguity of the Muscovite folklore image, his national and social interpretation are considerably caused by historical, political, and psychological peculiarities of Ukrainian history.

Key words: folk anecdote, tradition, image, Muscovite.

В статье исследуются современные народные анекдоты о москалях. Акиентировано на понимании анекдота как одного из наиболее продуктивных и популярних жанров, который способен к трансформачиям и может приспосабливаться к новым жизненным реалиям.

Констатировано, что сложность и неоднознчность фольклорного образа москаля, его национальная и социальная трактовки обусловлены историческими, политическими, психологическими особенностями украинской истрии.

Ключевые слова: народный анекдот, традиция, образ, москаль.

В усі численні драматичні та трагічні періоди для українців гумор завжди був засобом самозбереження. Це одна 3 найяскравіших рис національного характеру. В. Храмова в передмові до збірки «Українська душа» справедливо зазначає: «Нація, попри релігійну формащзію душі, щуо йила з Візантї̈, а також трагічний історичний досвід, демонструє величезну життєлюбність $i$ життєздатність з орієнтацією на сьогодні, а не на трансцендентну далечінь» [Храмова 1992:29]. 
На думку I. Кімакович, глибоке вивчення народної сміхової культури, аналіз іiі історичної динаміки «доконче необхідне для вияву істотних стереотипів народного світогляду, поза якими неможливе вивчення украйнської ментальності» [Кімакович 1996:3].

До аналізу сміхових явищ української культури зверталися в своїх працях М. Драгоманов, М. Сумцов, В. Гнатюк, І. Франко, А. Кримський, Г. Нудьга, О. Дей, Л. Махновець, Г. Крекотень, М. Яценко, Б. Деркач, В. Косяченко, О. Курочкін, О. Щербатюк, Р. Кирчів, І. Кімакович. Проте багато питань ще й сьогодні потребують глибокого вивчення. Так І. Кімакович у дослідженні «Традиційний анекдот у контексті сміхових явищ української культури» наголошує: «Питання про історичну динаміку народного світогляду в сфері сміхової творчості, про особливості ї̈ вияву в окремих видах $i$ жанрах народного та професійного мистецтва, про жанрову специфріку жанрів все ще чекають глибокого розгляду на широкому фактичному матеріалі» [Кімакович 1996:3].

Нині актуальним, на нашу думку є звернення до традиційного анекдоту як фольклорного жанру малої форми, що, на думку багатьох дослідників народної сміхової культури, є одним із найпродуктивніших та найпопулярніших жанрів.

I. Кімакович так визначає провідні риси народного анекдоту: «узагальнення життєвого досвіду, фабульність, установка на достовірність, здатність до сюжетних трансформаџій, спровокованих комунікативними потребами, забезпечують анекдоту популярність у просторі та часі» [Кімакович 1996:171].

Питання про те, який твір словесного народного мистецтва можна вважати традиційним - непросте, адже жанр анекдоту передбачає швидку реакцію народу на ті чи ті явища, події, вчинки людей. Лаконізм, що притаманний анекдоту, є виявом уміння народного генія побачити та висловити найяскравіші, найвиразніші риси явищ, подій, учинків людей. Традиція ж передбачає тривале в часі відтворення основного змісту та форми фольклорного твору, що демонструють певні ментальні стереотипи національної свідомості. 
У названій вище праці I. Кімакович визначає умови, за яких новостворений анекдот приймається фольклорною традицією: «сюжети стають традиційними, коли виконується хоча б дві умови. По-перше, потрібно, щзоби зафіксовані в сюжетах явищуа та життєві узагальнення були ціккавими для широкого кола слухачів за різних обставин: з'ява сюжетів зумовлюється їхньою актуальністю. I по-друге, такий сюжет має бути здатним до трансформацій, щзораз пристосовуючись до нової життєвої реальності: популярність зумовлюеться комунікативною спроможністю» [Кімакович 1996:17].

На думку Г. Магас, «для органічного вливання інновацій у фольклорну традицію, потрібно, щзоб вони базувались на грунті здобутків попередніх поколінь, виявляли тяглість щзодо узвичаєних досягнень, знань, уявлень. Постійний взаємовплив традиційних та інновацүійних форм сприяє розвитку загальнонацііональної традиції» [Магас 2013:165].

Саме здатність до трансформацій, уміння народу присосуватися до нової життєвої реальності й визначають динаміку фольклорної традиції.

У дослідженні «Архетип і основа художньої традиції» І. Зварич зазначає: «традиція мистецтвва слова (власне, як і всяка традищія) - цее величезний об'єм інформацуї, яка знаходиться в постійній динаміці: зазнає впливу новацій, деформується в них, багато ї̈ елементів забуваються, втративши продуктивність. Тобто традиція - изе постійна, рухлива система, яка містить y собі потенцію майбутнього $і$ зберігає всі стадії минулого» [Зварич 2005:6].

Ми погоджуємося $з$ думкою М. Фурси про те, що «інноваџіï виступають не запереченням традийї як такої, а витворюють протилежність в самій mрадийї̈» [Фурса 1996:26].

Особливе місце в гумористичній фольклорній спадщині займають анекдоти про москалів. Саме ці твори демонструють тісний взаємозв’язок традиційного і новітнього.

Відповідно до тематичної класифікації, ці твори можна віднести до соціально-побутових анекдотів [Кімакович 1996:171]. 
Відомо, що в Словнику української мови, укладеному Б. Грінченком, наведено 56 значень та форм слова «москаль». Серед них: сорт льону, сорт часника, вид комах, північно-східний вітер, вид консервованих оселедців і т.д. Найбільш уживані значення названої лексеми - «великорос (росіянин)» та «російський солдат». Активного використання в сучасному значенні етнонім «москаль» набуває в XVII-XVIII ст., коли українські землі стали частиною Російської імперії. Так почали називати солдат Російської армії, які складали окрему соціальну групу. Так із етноніма слово «москаль» перетворюється на назву представника певної соціальної групи і означає «солдат», «військовий» [13].

Протягом розвитку історії стосунків Україна / Росія наш народ уважно стежить за подіями, глибоко аналізує внутрішні та зовнішні вияви цих зв'язків, формує власне ставлення до них. Результати такого аналізу можна побачити, звернувшись до фольклорного образу москаля.

Сучасні значення лексеми «москаль» $є$ результатом глибоких роздумів українців щодо політичних, соціальних та морально-етичних чинників розвитку нації. Цей традиційно негативно маркований фольклорний образ нині набирає нових значень: 1) вояк чужоземної армії, що вторглася на територію України; 2) аморальний представник українського суспільства, носій деструктивного способу мислення, котрий, мешкаючи в Україні, шкодить їй ізсередини. Досить популярним $є$ сьогодні таке трактування поняття «москаль»:

1) «Москаль» - ие не житель Росії.

Це та падлюка, яка живе на

Україні в якій все не подобається:

ні їжа, ні мова, ні наші вродливі жінки.

Але ж і до Росії ия тварюка їхати не хоче! [17];

2) Москаль - ие падлюка:

Лінива, брехлива

Та ще й матюклива.

Живе в Україні, 
Пожовує сало,

Й при ирьому кричить,

Як бандери достали.

За путіна горло щосил надриває

Й своїм землякам щииро смерті бажає.

Якщео, любий друже,

Ти зустрів иџю падлюку -

Жени без вагань ї̈ в путінську дупу! [18].

Найяскравіше народні оцінки виявляються в таких жанрах фольклору як прислів’я та приказки, соціально-побутові пісні, соціально-побутові казки та анекдоти.

Фольклорний образ москаля - складний i неоднозначний. Його національне на соціальне трактування продиктовані історичними, політичними, психологічними особливостями української історії.

Як правило, цей образ постає у фольклорній традиції в двох соціальнопсихологічних варіантах. Це москаль-солдат (можливо, українець - вояк російської армії) та москаль-росіянин, представник українського суспільства, який ментально відрізняється від українця. Він - носій «інших», «чужих» цінностей, що $\epsilon$ неприйнятними для представника української культурної традиції.

Слід відзначити, що в народних оцінках цих фольклорних типів $є$ певні відмінності. Народ тонко відчуває психологічні зміни, що відбуваються 3 людиною, яка змушена виживати в чужому неприродному оточенні. Тому образ москаля-солдата осмислюється як уособлення людини, що згрубіла у війську, втратила зв’язки 3 національним, родинним оточенням, отже, і 3 моральноетичними орієнтирами свого етнічного середовища. Часто москаль (колишній земляк) сприймається як аморальна людина. Тому 3 ним слід поводитися обережно. Крім того, навіть якщо він повернувся зі служби відносно здоровим фізично і морально, він, як правило, вже не має трудових навичок, притаманних селянинові і не зможе пристосуватися до нормального життя. 
Другий тип (москаль, що є росіянином за походженням), як правило, фольклорною свідомістю осмислюється через категорії «інший», «чужий». При всій толерантності, притаманній нашому народові, терпимості щодо інших націй, українці постійно відчували цю «іншість». В. Брехуненко зазначає: «Увесь час українці демострували, що сприймають московитів / росіян як цілковито «інших», а Московію / Росію як чужу незвідану планету. Особливо це стало помітно після Переяславської ради 1654 р., коли доти епізодичні контакти переросли в тісніші стосунки і вже не тільки вище православне духівництво та частина козаків, а й ширший загал українського суспільства отримав змогу роздивитися московитів зблизька. Принесло це мало втіхи. Переяслав 1654 р., який з точки зору Б. Хмельницького був суто тактичним кроком, призначеним використати Москву для остаточної перемоги над Річчю Посполитою, а також для міжнародного визнання відновленої Української держави та ії правителягетьмана, став не відправним пунктом зближення, а каталізатором взаємного несприйняття, війн і трагедій» [Брехуненко 2016:9-10].

Цей традиційний фольклорний образ москаля репрезентовано багатоманітністю варіантів. Це москаль-ворог, із яким ведеться війна (хитрий, зрадливий і підступний); це москаль-командир у царській армії та москальсолдат, який квартирує в селянській родині. Вони марковані підкреслено негативно. Народне ставлення до москаля яскраво виявлено в прислів’ях та приказках:

1) москаль-ворог, «чужий»:

Москаль не свій брат, не пожалує [Українські приказки 1993:76];

3 Москалем дружи, а камінь за пазухою держи (там само);

Cmapicmь не padicmь, а Москаль не брат [Українські приказки 1993:708];

2) москаль як людина, позбавлена моральних пріоритетів:

Москалики, соколики, позї̈али ви наші волики, а як вернетесь здорови, то поїсте й корови [Українські приказки 1993:76];

Мабуть москаль тоді красти перестане, як чорт молиться Богу стане [Українські приказки 1993:77]; 
На вовка помовка, а москаль кобилу вкрав (там само);

Коли москаль каже сухо, то піднімайся по вухо (там само);

Москаль тоді правду скаже, як чорт молищьия стане (там само);

Казав москаль право, та й збрехав браво (там само);

У йому стільки віри, як в москалеві правди

[Українські приказки 1993:708];

москаль, який зверхньо ставиться до інших:

На грош амунииії, на десять амбіиії [Українські приказки 1993:77];

Москаль ликом чваниция цे кожному під ніс 3 ним пхаєция [Українські приказки 1993:7].

Цікаво, що прислів'я та приказки як жанр, який вирізняється лаконічністю та місткістю, репрезентує категоричність народних оцінок щодо морально-етичних рис москаля. Інші ж жанри ілюструють більш обережне ставлення до цього соціально-психологічного типу. Так, аналізуючи зміст «народної» частини вертепу, О. Воропай зазначає: «Як відомо, у XVIII-му столітті, а особливо після поразки під Полтавою року 1709, на Украӥні були «постої» російських військ, що дуже допікали намому населенню. Хоч населення москалями було незадоволене, все ж у Сокиренському вертепі ми не зустрічаємо такого гостро негативного ставлення персонажів до москаля, як до поляка. Це, очевидно, тому, що москалі, як окупанти Украӥни, могли контролювати публічні виступи. Крім того, відігравали тут певну ролю $i$ віросповідні мотиви» [Воропай 1993:85].

Таку ж обережність демонструє соціально-побутова казка, що містить великий масив творів про хитрого та винахідливого солдата («Як солдат із зуба борони юшку варив», «Солдат борщ солить») [Калинова сопілка 1989:598].

Казка «Солдат та сповіді» репрезентує образ москаля-солдата як аморальної людини, яка не має в душу нічого святого: «Сnовідається солдат $i$ чує, щзо у батюшки часи дзеленькають. Він взяв та й украв їх» [Калинова сопілка 1989:291]. 
Анекдоти про москалів із огляду на лаконічну форму та особливості функціонування (розповідаються вони в невеликому колі однодумців, людей, яким можна довіряти) як правило, є зразками гострого, іноді «чорного» гумору.

Цікаво, що сьогодні в народному середовищі побутують як твори, що виникли в XIX-XX ст., так і новітні зразки. Образ москаля функціонує в межах традиції: він маркований підкреслено негативно. Це цілком зрозуміло з огляду на те, що сутність соціально-психологічного типу москаля не змінилася (великоруські амбіції, зверхність, неповага до інших націй, культур, міф про вибраність росіян, причетність до високорозвиненої універсальної культури, прагнення загарбати якомога більше «ісконно русских земель»). Тому образ москаля-солдата, що втратив моральні орієнтири під час служби у війську Російської імперії, образ москаля-загарбника - вояка червоної армії, що топчеться по західноукраїнських землях, зомбованого радянською ідеологією, цинічного i жорстокого органічно трансформується сучасною фольклорною свідомістю. Але якщо перший тип москаля викликає в народі бажання бути обережним, то два наступних - боротися з ним усіма можливими засобами:

1) Два куми копають на городі велику яму. Підбігає маленький син одного з них:

- Tату, тату, а то ви яму для москаля копаєте?

Кум, загордивиись, - другому:

- Ач, так емале, а вже газда! [14];

2) Москалик в Києві: - Извинище, как папасц̧ь в расийскае пасольства?

- Дуже просто: навів ракетнищњю, націлився і пустив! [15].

У праці «Етюди до студій над українським народним анекдотом» Р. Кирчів відзначає наявність у традиційних творах мотивів соціального характеру, які свідчать про відчуття українцями своєї «іншості», «окремішності» від представників іноетнічних груп населення: «Вони звучать, зокрема, в сюжетах про взаємини украӥнського селянина, міського простолюдина $з$ «інородияями»-представниками іноетнічних груп населення 8 Україні і з урядовцяяи, особливо з функціонерами низових, місцевих гілок влади. 
Бінарна опозиція «ми» $i$ «вони» простежується в ц̧их сюжетах на тільки по лінії етнопсихологічної, культурно-побутової, релігійної, мовної відмінностей, але й нерідко усвідомлення соцуіальної несумісності ц̆ опозиційності» [Киричів 2008:58].

Останні події в Україні спричинили до появи цілої гілки анекдотів, у яких народ гостро i досить категорично висловлює своє ставлення до типу «москаль»:

1) Ти знаєм, я вже боюся на вулиці розмовляти по-московськи.

- Чому? Ти боїися, щуо тебе можуть образити бандерівці?

- Ні, я боюсь, щзо прийдуть москалі й будуть мене захищати [14];

2) Вуйку Стефане, вуйку Стефане! Що то виробите?! Навіщо ви берізку рубаєте? Така струнка, молоденька, так око зеленими листочками милувала, а ви ї̈ геть!

- Oй, сусіде, й не кажіть, в самого сериче кров'ю обливається, але мушу те зробити - прийдуть москалі, побачать берізку $і$ скажуть: «Вот ісконно русскій пєйзаж!» [14];

3) Таємна вечеря. Ісус звертається до учнів: «Сьогодні один із вас зрадить мене». I всі зачали питати: “Чи иุе не я, Господи?»- спитав Петро, «Чи не я иее, Господи?»- спитав Іван, і так усі по черзі перепитали... Аж ось Iуда Iскаріот запитує: «Не я лі ета, Гасподь?» [14];

4) Крим. Приходить хлопчик зі школи додому й каже батькові:

- в в нас у школі усі розмовляють украӥнською мовою. Я анкету заповнював й в графі нащчіональність написав, щзо я украӥнещ̧ь.

Батько:

- Так значєт ти українець? Ладно. Я больше не буду возить тєбя на машине, будеш єздить на автобусє, как все бєндеровцьь. У школу буду давать тєбе 1 гривну, а не 2 \$. I жрать ти будеш картошку, а не ікру. Як нравеца біть українцем?

Син:

- Я тільки 5 хвилин украӥнець, а як я вас москалів ненавиджу [16]; 
5) Німещь має жінку й коханку. Любить жінку.

Франиуз має жінку й коханку. Любить коханку.

Жид має жінку й коханку. Любить маму.

Москаль має жінку й коханку. Любить Путіна... [15].

Таке трактування образу москаля у фольклорі не $є$ свідченням національної нетерпимості українців, це результат глибокого аналізу поведінки людини-представника певного суспільного прошарку, що зумовлена соціальнопсихологічними чинниками. Ми погоджуємося 3 думкою Г. Гачева: «Багатоваріантність народів та їх культур - ие скарб людства. Подібно до того, як у симфонічному оркестрі кожний інструмент має свій тембр, так $i$ кожний народ наділений особливим талантом бачити світ $і$ творити речі таким чином, який не притаманний народові-сусідові. Таким чином, народи на планеті доповнюють один одного і нам необхідно не просто мати терпимість, толерантність до відмінностей між народами та їх культурами, але відчувати до них любов так само, як ми поважаємо розподіл праці $у$ виробнищтві [Гчев 2007].

Отже, наш народ завжди був і $є$ відкритим для спілкування, обміну традиціями, творчої співпраці. Разом із тим він справедливо вимагає поваги до себе, своєї культури, не терпить насильства, зверхності, хитрості, підлості, пристосуванства. Саме в цій національній концепції слід шукати витоки народного ставлення до москаля, що яскраво репрезентований у народному анекдоті.

\section{БІБЛІОГРАФІЯ}

1. Брехуненко 2016 - Брехуненко В. «Братня» навала. Війна Росії проти України XII - XXI ст. / В. Брехуненко В., Ковальчук В., Ковальчук М., Корнієнко В. - К., 2016. - 248 с.

2. Воропай 1993 - Воропай О. Звичаї нашого народу [Етнографічний нарис] / Олекса Воропай. - К. : Оберіг, 1993. - 600 с.

3. Гачев 2007 - Гачев Г. «Лебединая песня национальных культур. У них впереди не жизнь, а смерть» : (Стенограмма лекции известного российского 
литературоведа, культуролога, доктора филологических наук Георгия Гачева, прочитанной 17 мая 2007 года в клубе - литературном кафе Bilingua в рамках проекта «Публичные лекции Полит.ру») [Електронний ресурс] / Г. Гачев. Режим доступу: http://polit.ru/article/2007/05/24/kulturosob.

4. Головаха-Хікс 1997 - Головаха-Хікс I. С. Оповідач та динаміка усної прозової традиції: дис. ... канд. філол. наук : 10.01.07 / Інна Свгенівна ГоловахаХікс. - К., 1997. - 175 с.

5. Зварич 2005 - Зварич I. М. Архетип і основа художньої традиції : Конспект лекцій / Ігор Михайлович Зварич / Чернівецький національний університет ім Ю. Федьковича. - Чернівці : Рура, 2005. - 47 с.

6. Калинова сопілка 1989 - Калинова сопілка. Антологія української народної творчості. Казки, анекдоти, легенди, перекази, оповідання [упорядкув., пер., ст. та прим. О. Ю. Бріциної, Г. В. Довженок, С. В. Мишанича]. - К. : Веселка, 1989. - 615 с.

7. Кімакович 1996 - Кімакович I. I. Традиційний анекдот в контексті сміхових явищ української культури: дис. ... канд. філол. наук : спец. : 10.01.07 / Ірина Ігорівна Кімакович - К., 1996. - 248 с.

8. Кирчів 2008 - Кирчів Р. Етюди до студій над українським народним анекдотом / Роман Кирчів.- Львів : Інститут народознавства НАН України, 2008. -268 c.

9. Магас 2013 - Магас Г. Б. Народнопісенні жанри Стрийщини : традиції та інновації: дис. ... канд. філол. наук : спец. : 10.01.07 / Галина Богданівна Магас. - Л., 2013. - 207 арк.

10.Українські приказки, прислів’я і таке інше 1993 - Українські приказки, прислів'я і таке інше. Уклав М. Номис [упорядкув., прим. та вступна ст. М. М. Пазяка]. - К. : Либідь, 1993. - 768 с.

11.Фурса 1996 - Фурса М. В. Філософія національної свідомості (методологічний аспект) / М. В. Фурса. - Львів: Інститут українознавства ім. І. Крип’якевича НАН України, 1996. - 28 с. 
12.Храмова 1992 - Храмова В. М. До проблеми української ментальності : Замість передмови / В. М. Храмова // Українська душа. - К., 1992. - С. 3-36.

13.https://uk.wikipedia.org/wiki/

14.http://blogs.korrespondent.net/blog/users/3330479-anekdoty-pro-mos kaliv 15.http://www.pidmanula.narod.ru/anekdot9.htm

16.https://vk.com/topic-2186134_3121803

17.http://otvet.bigmir.net/question/948419

18.https://www.facebook.com/permalink 